\title{
ARTICLE
}

\section{Molecular taxonomy and community dynamics of Actinobacteria in marine sediments off central Chile}

Taxonomía molecular y dinámica comunitaria de Actinobacteria en sedimentos marinos de Chile central

\author{
Selim S. Musleh ${ }^{1}$, Daniel Gomez-Uchida ${ }^{2}$, Carola Espinoza ${ }^{1}$, Nathaly \\ Ruiz-Tagle $^{3}$, Alexis Fonseca ${ }^{1}$ and Víctor A. Gallardo ${ }^{1}$
}

\author{
${ }^{1}$ Department of Oceanography, Universidad de Concepción, P.O. Box 160-C, Concepción, Chile. smusleh@udec.cl \\ ${ }^{2}$ Department of Zoology, Universidad de Concepción, P.O. Box 160- C, Concepción, Chile \\ ${ }^{3}$ Centro de Biotecnología, Universidad de Concepción, P.O. Box 160- C, Concepción, Chile
}

\begin{abstract}
Resumen.- Se usó pirosecuenciación de la región V6 del gen 16S del ARNr para caracterizar la diversidad y la dinámica espaciotemporal de unidades taxonómicas operacionales (OTUs) del filo Actinobacteria, los que fueron aislados desde sedimentos provenientes del Sulfureto de Humboldt frente a Chile central. Este substrato es rico en compuestos azufrados y material orgánico lo que mantiene una vasta comunidad microbiana que experimenta cambios estacionales en respuesta a regímenes oceanográficos contrastantes. Se identificaron 498 OTUs distribuidas en 7 órdenes, 47 familias, 122 géneros, (5 de los cuales son ampliamente reconocidos por sus aplicaciones biotecnológicas), y 56 especies. El análisis temporal reveló que algunos OTUs presentan diferencias significativas en abundancia, índices de diversidad y riqueza, las que generaron una agrupación de las muestras asociada a la fecha de muestreo (estación del año) y no a la profundidad del sitio de muestreo. Debido a que las Actinobacteria son mayormente aeróbicas, las altas concentraciones de oxígeno disuelto que ocurren en la zona en el otoño-invierno austral, representan condiciones ambientales beneficiosas para este filo, no así las de primavera-verano austral cuando prevalece la hipoxia. El presente trabajo se benefició de la aplicación de métodos cultivo-independientes (métodos moleculares) para evaluar la diversidad taxonómica y examinar la dinámica de uno de los grupos de bacterias presentes en el Sulfureto de Humboldt reportado como una fuente potencial e inexplorada de metabolitos secundarios.
\end{abstract}

Palabras clave: Actinobacteria, Sulfureto de Humboldt, ecología bacteriana

\begin{abstract}
We used amplicon sequencing of the 16S rRNA gene to characterize the diversity and assess temporal and spatial patterns of Actinobacteria operational taxonomic units (OTUs) extracted from sediments of the Humboldt Sulfuretum located off the coast of central Chile. The sediment of this zone is rich in sulfur compounds and organic material and supports a vast microbial community that experiences seasonal changes in response to contrasting oceanographic regimes. We distinguished 498 OTUs distributed among 7 orders, 47 families, and 122 genera ( 5 of these have been widely recognized for their biotechnological applications), and 56 species. The temporal analyses indicated that some OTUs underwent significant temporal changes in abundance, richness, and diversity that allowed samples to be grouped by sampling dates (seasons) but not by sampling depth or location. Since Actinobacteria are mostly aerobic, higher concentrations of dissolved oxygen near the bottom during the austral autumn-winter seasons result in a more benign environment for this phylum than the upwelling-favorable spring-summer seasons when waters over the shelf are oxygen-deficient. To evaluate the taxonomic diversity and inquire into the community dynamic of Actinobacteria present in the Humboldt Sulfuretum and reported as a potentially untapped source for secondary metabolites this work benefited from culture-independent (molecular) techniques.
\end{abstract}

Key words: Actinobacteria, Humboldt Sulfuretum, bacterial ecology

\section{INTRODUCTION}

The benthic habitat of the Humboldt Current System in the Southeast Pacific off Chile is characterized by an oxygen minimum zone (Gallardo 1963) and seasonally variable dissolved oxygen conditions (Ahumada \& Chuecas 1979, Gallardo et al. 1995, Paulmier et al. 2006, Sobarzo et al. 2007, Fuenzalida et al. 2009). This habitat supports a vast and diverse community of giant bacteria (Gallardo 1963, Gallardo
1975, 1977a, b; Fossing et al. 1995, Gallardo \& Espinoza 2007a, b); smaller prokaryotes (Tremberger et al. 2010); and microbial eukaryotes (Høgslund et al. 2008), and is now known as the Humboldt Sulfuretum (HS: Gallardo et al. 2013a, b). Despite efforts, knowledge about the taxonomy, diversity, dynamics, and biotechnological value of this complex microbial community (Li et al. 2013), is still in its infancy. 
Among major bacterial lineages the phylum Actinobacteria represents one of the richest taxa as revealed by culture and molecular approaches (Rappé \& Giovannoni 2003); it comprises 5 sub-classes, 9 orders, 55 families, and 240 genera, from which $\mathrm{ca}$. 3,000 species are currently known (Goodfellow $\&$ Fiedler 2010). They include aerobic and facultative anaerobic gram-positive bacteria with a high DNA G+C content, ranging from $51 \%$ in some Corynobacteria to more than $70 \%$ in Streptomyces and Frankia (Hogg 2005). Within the Actinobacteria, Actinomycetes are a recurrent component of marine systems comprising taxa with highly variable physiological and metabolic properties, which form stable and persistent communities (Jensen et al. 2005). They are morphologically diverse (e.g., rod or coccoid, fragmented hyphae or differentiated branched mycelia; Adegboye \& Babalola 2012) and possess an unparalleled ability to produce secondary metabolites (Cho et al. 2006, Manivasagan et al. 2013). These compounds often serve as leads for the development of new pharmaceutical drugs with clinical applications, e.g., bonactin, antibacterial and antifungal; aureoverticillactam, anticancer (Bérdy 2005, Fiedler et al. 2005, Lam 2006).

Next-generation amplicon sequencing of 16S rRNA genes provides a powerful, culture-independent tool to assess temporal and spatial changes among bacterial communities (Fandinoet al. 2001, Galand et al. 2009, Caporaso et al. 2011, Ulloa et al. 2012, Sul et al. 2013) as well as to explore and estimate bacterial richness and diversity (Jensen et al. 2005, Deutschbauer et al. 2006, Sogin et al. 2006, Ward \& Bora 2006, Amaral-Zettler et al. 2010, Goodfellow \& Fiedler 2010, Zinger et al. 2011, Bik et al. 2012). Amplicon pyrosequencing of the V6 region of the 16S rRNA gene (V6 pyrotags, hereafter) was used to assess the taxonomic composition and community structure of Actinobacteria found in the HS off central Chile. The first goal was to classify the local taxonomic diversity of this group using global alignment for sequence taxonomy (GAST) and identify relevant taxa. The second goal was to test for spatial and temporal patterns among sampling sites (stations) in the relative abundance composition of operational taxonomic units (OTUs). The designation of OTUs based on molecular criteria is the method of choice among bacterial ecologists to assess diversity (Pedrós-Alió 2012). Since off central Chile the diversity within macrobenthic communities showed a negative relationship with oxygen concentration and depth (Gallardo et al. 1995), it was hypothesized that the Actinobacteria community could also show such related patterns. In addition, and because Actinobacteria are primarily aerobic (Hogg 2005), it was hypothesized that any temporal changes in the Actinobacteria community could be linked to the two different seasonal oceanographic regimes in the study area with low-oxygen over the shelf due to increased upwelling during the spring-summer and high oxygen due to diminished upwelling and the presence of oxygenated surface waters over the shelf during autumn-winter (Ahumada \& Chuecas 1979, Gallardo et al. 1995, Paulmier et al. 2006, Sobarzo et al. 2007, Fuenzalida et al. 2009).

\section{MATERIALS AND METHODS}

\section{STUDY ZONE AND SAMPLING}

This study involves the Bay of Concepcion (BoC) and the adjacent continental shelf off central Chile (Fig. 1). Four samplings stations were visited in the study area (Table 1 ), three located inside the BoC (station 1, $15 \mathrm{~m}$; station 4, $27 \mathrm{~m}$ and station 7,35 m depth), and one in the adjacent continental shelf (station 18, $88 \mathrm{~m}$ depth). At each location triplicate samples were obtained at four periods: December (end of austral spring) 2007, April (end of austral summer) 2008, September (end of austral winter) 2008, and January (austral summer) 2009.

The sediment was collected using an Oktopus mini-multicorer equipped with 6 plexiglass tubes $(9 \mathrm{~cm}$ diameter, $40 \mathrm{~cm}$ long) and a mono-corer with a single $1 \mathrm{~m}$ long, $5 \mathrm{~cm}$ in diameter plexiglass tube. Each sediment sample was immediately subsampled onboard into smaller acrylic tubes and transported refrigerated to the laboratory where the first $5 \mathrm{~cm}$ of each replicate were mixed and, from the resulting mix, a final aliquot of $0.5 \mathrm{~g}$ was used for DNA extraction. In total, 16 (4 stations $\mathrm{x}$ 4 seasonal) samples were extracted.

\section{DNA EXTRACTION AND PYROSEQUENCING OF 16S RRNA BACTERIAL GENES}

The $0.5 \mathrm{~g}$ aliquot samples obtained as above were washed 3 times with phosphate buffered saline and extracted using the PowerSoil DNA isolation kit (MoBio Laboratories, Inc). DNA quality and concentration were evaluated by absorbance readings taken at A260 and A280 in an Infinite F200pro (Tecan Group Ltd., Suitzerland). Three DNA extractions were performed from each sampling site which were subsequently pooled and lyophilized using a Speed Vac System. Massive and parallel tag sequencing of the hypervariable V6 region of the 16S rRNA bacterial gene (Sogin et al. 2006, Huber et al. 2007, Huse et al. 2007) among pooled isolates was done in a 454 GS-FLX Roche housed at the Marine Biology Laboratory, Woods Hole, Massachusetts, USA (Fakruddin \& Chowdhury 2012). 
Figure 1. Map of the study area showing the position of sampling stations. In brackets the depth $(\mathrm{m})$ where samples were collected / Mapa del área de estudio señalando la ubicación de las estaciones de muestreo. Entre paréntesis la profundidad en metros de los muestreos

Table 1. Sampling sites, dates, depth, and V6 pyrotag numbers in benthic samples collected in the Bay of Concepcion ('BoC stations' 1, 4 and 7) and open ocean ('off BoC' station 18), central Chile (sampling station numbers correspond to those of the 1994 Thioploca-Chile Expedition (see Gallardo et al. 2013a) / Sitios de muestreo, fechas, profundidad y número de pyrotags V6 en las muestras bentónicas recolectadas en la Bahía de Concepción ('estaciones BoC' 1,4 y 7) y en mar abierto ('estación 18 off

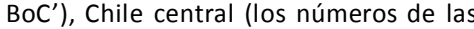
estaciones de muestreo corresponden a las de la Expedición Thioploca-Chile 1994 (ver Gallardo et al. 2013a)

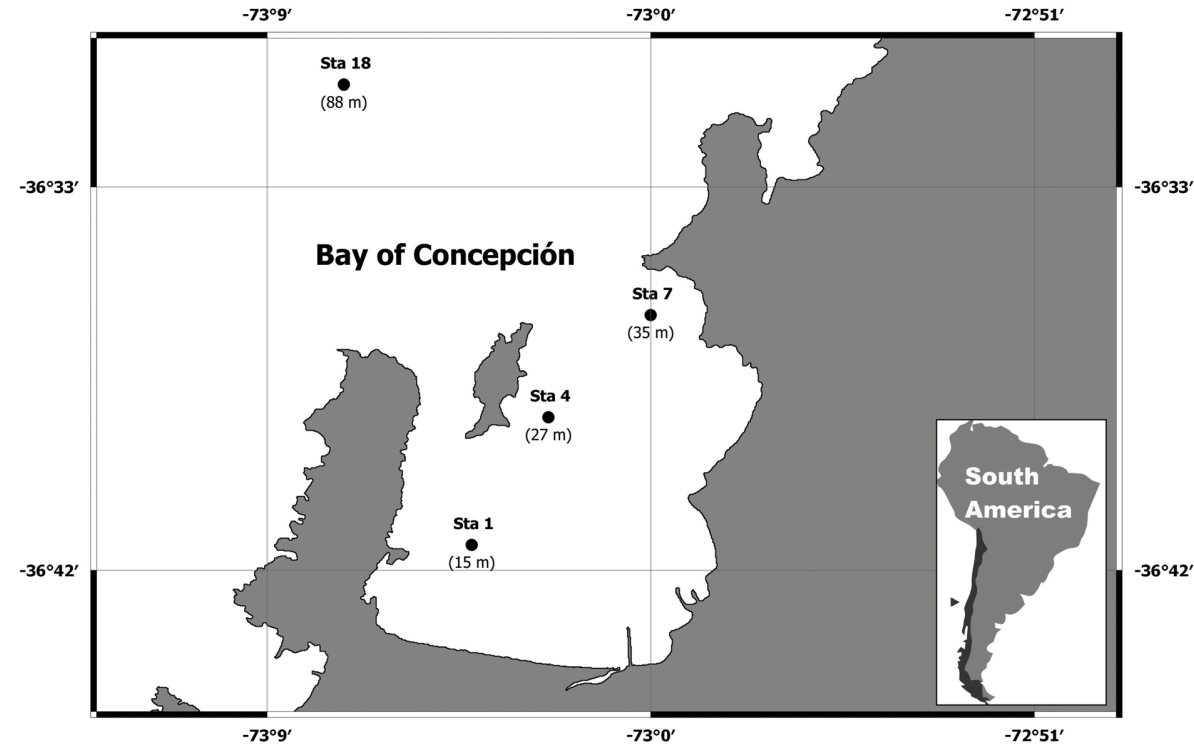

\begin{tabular}{clccccc}
\hline $\begin{array}{c}\text { Station } \\
\text { Nr. }\end{array}$ & \multicolumn{1}{c}{ Date } & Lat. ${ }^{\circ} \mathrm{S}$ & Long. ${ }^{\circ} \mathrm{W}$ & $\begin{array}{c}\text { Depth } \\
(\mathrm{m})\end{array}$ & $\begin{array}{c}\text { Total V6 } \\
\text { pyrotags }\end{array}$ & $\begin{array}{c}\text { Actinob. V6 } \\
\text { pyrotags }\end{array}$ \\
\hline 1 & December 2007 & 36.69 & 73.07 & 12 & 11166 & 172 \\
1 & April 2008 & 36.69 & 73.07 & 12 & 38348 & 307 \\
1 & September 2008 & 36.69 & 73.07 & 12 & 18140 & 716 \\
1 & January 2009 & 36.69 & 73.07 & 12 & 9713 & 79 \\
4 & December 2007 & 36.64 & 73.04 & 25 & 11414 & 154 \\
4 & April 2008 & 36.64 & 73.04 & 25 & 28067 & 450 \\
4 & September 2008 & 36.64 & 73.04 & 25 & 15099 & 794 \\
4 & January 2009 & 36.64 & 73.04 & 25 & 12427 & 28 \\
7 & December 2007 & 36.6 & 73 & 35 & 20225 & 387 \\
7 & April 2008 & 36.6 & 73 & 35 & 23890 & 369 \\
7 & September 2008 & 36.6 & 73 & 35 & 13437 & 1096 \\
7 & January 2009 & 36.6 & 73 & 35 & 13497 & 67 \\
18 & December 2007 & 36.51 & 73.12 & 88 & 24461 & 207 \\
18 & April 2008 & 36.51 & 73.12 & 88 & 15438 & 1426 \\
18 & September 2008 & 36.51 & 73.12 & 88 & 19044 & 1849 \\
18 & January 2009 & 36.51 & 73.12 & 88 & 22854 & 117 \\
\hline
\end{tabular}




\section{DNA TAXONOMIC ANALYSES}

After low quality sequences were trimmed (Huse et al. 2007), each V6 pyrotag was taxonomically assigned using a (GAST) pipeline (Sogin et al. 2006, Huse et al. 2008). All selected V6 sequences from all samples that were assigned to the phylum Actinobacteria were then distributed into the genus level.

\section{COMMUNITY STRUCTURE: OTU DIVERSITY AND RICHNESS}

V6 pyrotags were clustered into OTUs following Huse $e t$ al.'s (2008) method, which reduces OTUs overestimation (Huse $e t$ al. 2010) and is analogous to the PyroNoise method (Quince et al. 2011). High-quality V6 pyrotags $(\mathrm{N}=269,752)$ were organized in 19,750 OTUs using a $97 \%$ sequence similarity criterion (Huse et al. 2010). This method was adopted because bacterial sequences with similarities greater than $97 \%$ are typically assigned to the same species (Rosselló-Mora \& Amann 2001). The number of selected V6 pyrotags assigned by GAST to the phylum Actinobacteria amounted to 8,218.

Diversity for each of the 16 samples was estimated using the reciprocal Simpson's index $(D)$, according to: $D=1 / 1$ $\mathrm{S}\left(\mathrm{N}_{\mathrm{i}}\left(\mathrm{N}_{\mathrm{i}}-1\right) /(\mathrm{N}(\mathrm{N}-1))\right.$, where $N_{i}$ is the abundance of the $i$ th OTU in each sample and $N$ is the total number of OTUs. Inverse Simpson is sensitive to the level of OTUs dominance (Hansel et al. 2008) and effectively distinguishes between dominant and uniform diversity patterns (Zhou et al. 2002). Additionally, OTUs expected richness for each sample using CatchAll, which implements a parametric estimation method, was calculated (Bunge 2011). This analysis uses frequency count data to compute 'real' richness to account for potentially overlooked or unseen species richness.

Testing for spatial and temporal patterns proceeded in 2 steps: (A) the degree of correlation between OTUs relative abundances (semi-metric Bray-Curtis distance) and OTUs presence/absence matrices (metric Jaccard distance) using a Mantel test (Mantel \& Valand 1970) in R (R Core Team 2014) was measured. This analysis should assess whether changes in OTUs relative abundances were correlated with OTUs richness, which may be influenced by many V6 pyrotags of low relative abundance. Spearman's correlation coefficient $(\rho)$ between observed and randomized data matrices after 99,999 permutations was calculated using the vegan package (Oksanen et al. 2012) in R; (B) OTUs data sets were analyzed for spatial (Stations) and temporal patterns (dates of sampling-season) using a permutation multivariate analysis of variance, PERMANOVA(Anderson 2001, McArdle \& Anderson 2001). PERMANOVA on OTUs data sets in vegan using 99,999

${ }^{1}<$ http://vamps.mbl.edu> permutations were performed. Two-dimensional ordination plots were based on nonmetric multidimensional scaling (NMDS) (Kruskal 1964) using vegan's metaMDS procedure. GAST and OTUs data sets are available in the project ID ICM_VAG_Bv6 ${ }^{1}$.

\section{Results}

\section{Molecular TaXonomy}

GAST taxonomy classified 8,218 V6 pyrotags in the Actinobacteria phylum. The proportions of V6 pyrotags assigned by GAST at the different taxonomic levels are presented in Fig. 2. Within the phylum, 498 OTUs were distributed among 7 orders, 47 families, 122 genera, and 56 species. Actinomycetales was the dominant order (3,309 V6 pyrotags), whereas Acidimicrobiaceae was the dominant family with more than 600 V6 pyrotags. At the genus level, Mycobacterium

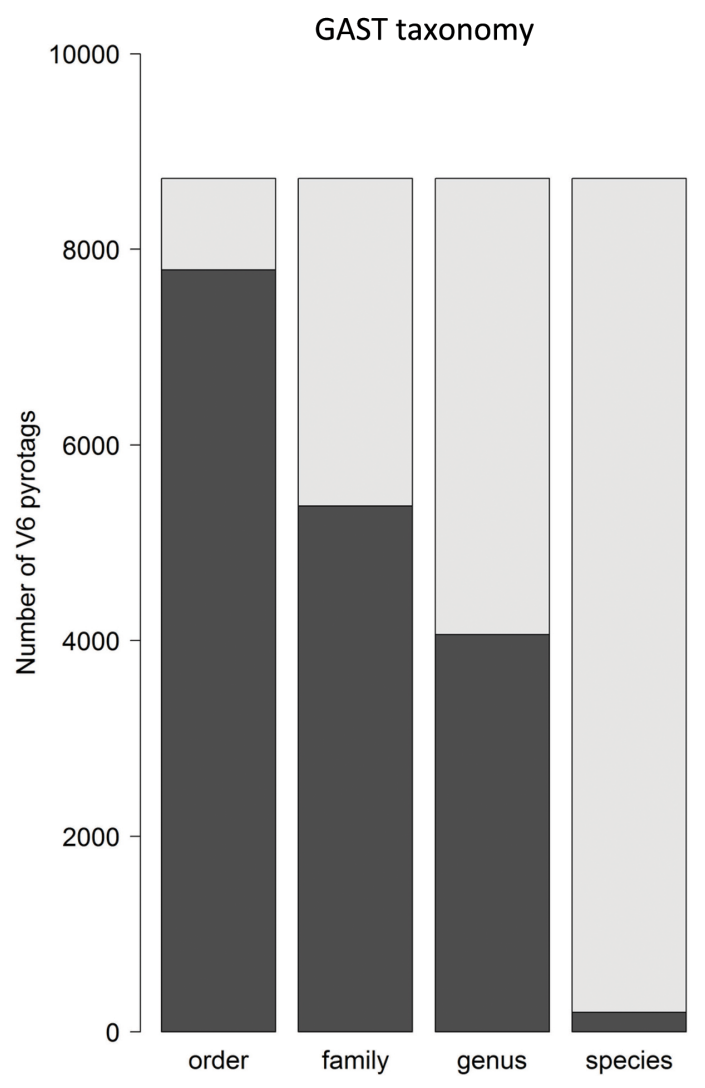

Figure 2. GAST taxonomy. Dark grey bars represent the number of V6 pyrotags with matches in databases; light grey bars represent the number $\mathbf{6} 6$ pyrotags with no matches in any database / Taxonomía GAST. Las barras gris-obscuro representan el número de V6 pyrotags con entradas en las bases de datos; las barras gris-claro representan el número de $V 6$ pyrotags que no tienen entradas en ninguna base de datos 
accounted for the majority of V6 pyrotags with more than 350 reads, followed by Conexibacter and Streptomyces. Many genera found in this community were classified as important producers of secondary metabolites with known biotechnological applications (Table S1).
Several V6 pyrotags had no matches to any genus $(4,662)$ or species $(8,523)$, and remained unclassified. All genera were plotted against their relative abundance after sample pooling (Fig. 3).

\section{GAST assigned Genus}

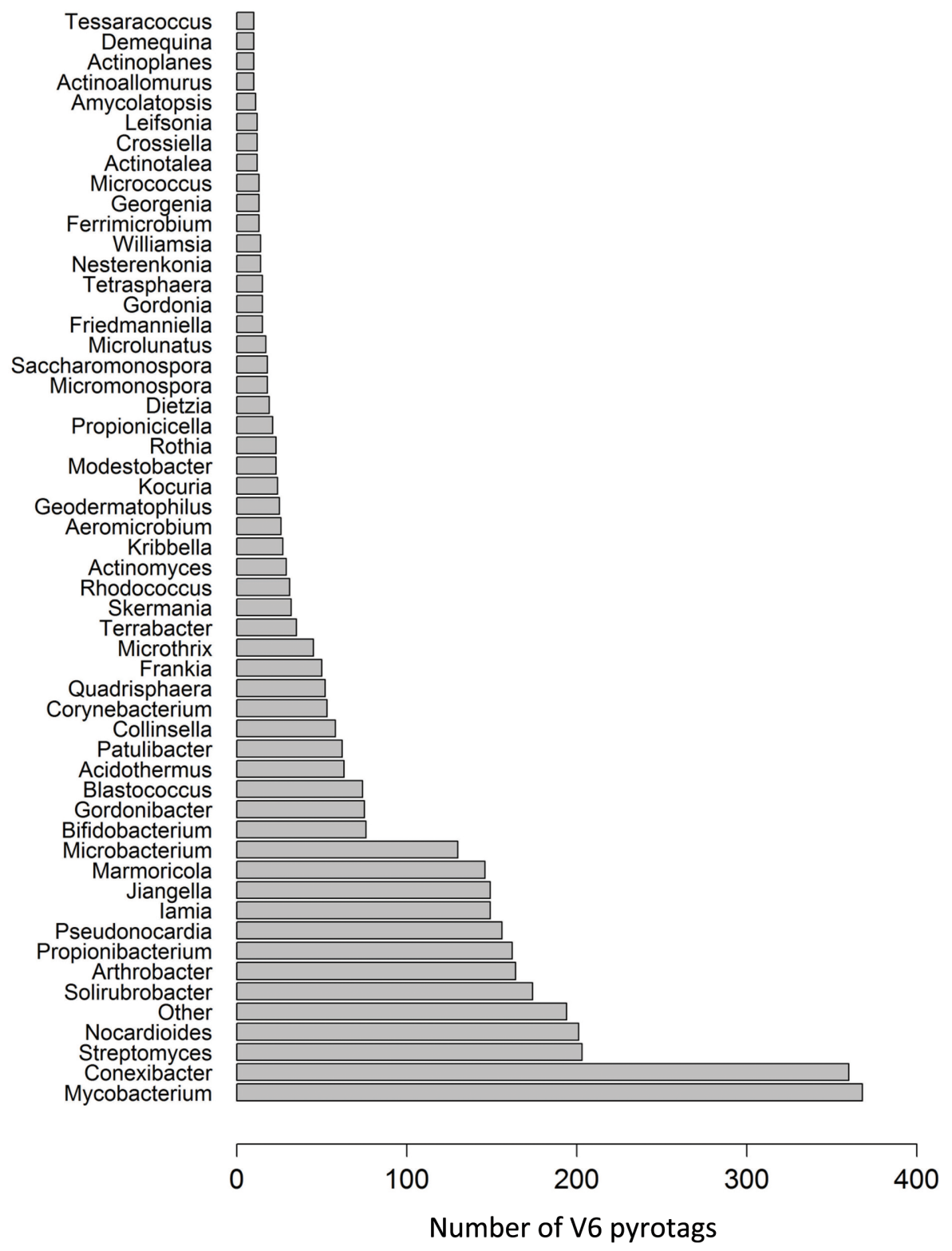

Figure 3. Relative abundance of HS Actinobacteria genera as identified through GAST / Abundancia relativa de los géneros de Actinobacteria presentes en las muestras del SH identificados usando GAST 


\section{Community Structure: OTUs diversity AND RICHNESS}

Actinobacteria showed changes in richness and diversity among samples (Fig. 4). In general, for all sampling sites the highest abundance of OTUs and species richness were observed in samples collected in September 2008 (transition between austral winter and austral spring). Conversely, the lowest number of pyrotags (a proxy for relative abundance) was seen in January 2009 in all stations (austral summer) (Table 1). Expected species richness from CatchAll varied between $744 \pm 99$ (Sta. 4 in September (end of austral winter) 2008) and $80 \pm 15$ (Sta. 1 in January (austral summer) 2009) and this trend was consistent with relative abundance and richness values. Mean expected richness was 300 OTUs, while the mean observed richness was 137 OTUs, indicating that approximately $45 \%$ of all OTUs from the phylum Actinobacteria potentially present at the study zone were sampled. Also, diversity $(D)$ was correlated with relative abundance and richness, showing the highest diversity values in September (end of austral winter) 2008.

A Mantel test showed a strong and significant correlation ( $\mathrm{r}=0.9037, P<0.005$ ) between OTUs relative abundance (Bray-Curtis) and presence/absence (Jaccard) matrices. PERMANOVA analyses on the Bray-Curtis matrix suggested significant differences among dates (season) of sampling ( $\mathrm{F}=$ 3.9426, $P<0.05)$, but not among stations (depth) $(\mathrm{F}=1.2336$, $P>0.05$; Table 2). These results were consistent with groups obtained through NMDS (Fig. 5). By date, samples clustered into 3 groups: (i) January (austral summer) 2009, (ii) December (end of austral spring) 2007-April (end of summer) 2008, and (iii) September (end of austral winter) 2008. In addition, among sampling sites 2 groups were found: a 'BoC group' (Sta. 1, 4 and 7) and an 'off BoC group' (Sta. 18).
Figure 4. Observed and expected richness (a), and diversity (b), among samples. Richness plotsshow: observed richness, dots; expected richness, bars; and standard error bars/ Riqueza observada y esperada (a) y diversidad (b) entre muestras. El gráfico de riqueza presenta: riqueza observada, puntos; riqueza esperada, barras; y barras de error estándar
Richness

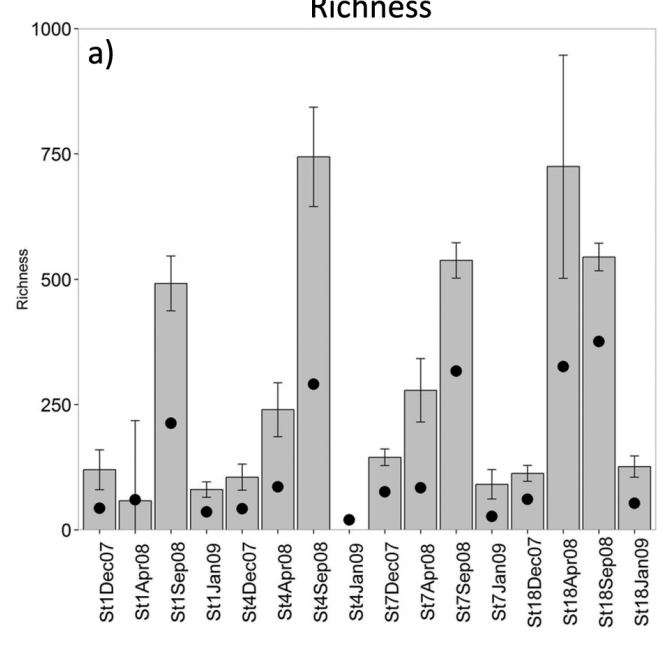

Diversity

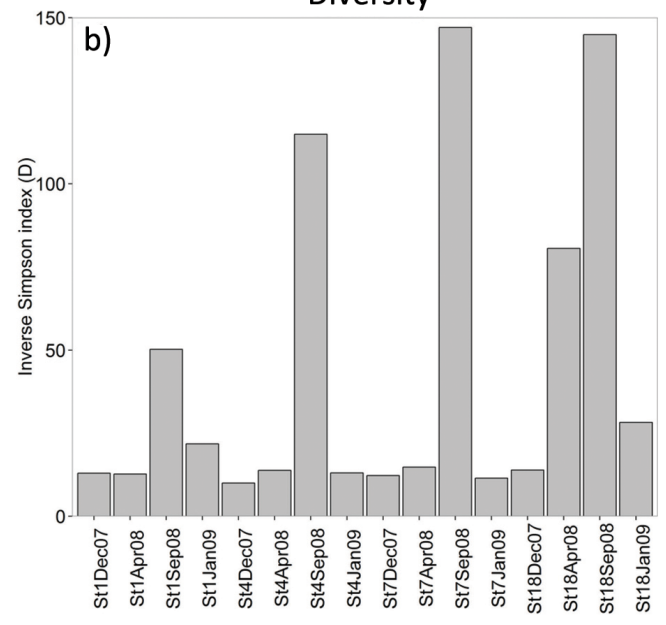

Table 2. Results of PERM ANOVA based on Bray-Curtis distances among samples using two grouping factors: sampling station and date of sampling / Resultados del análisis PERMANOVA basado en distancias de Bray-Curtis entre las muestras utilizando dos factores: estación de muestreo y fecha de muestreo

\begin{tabular}{ccccccc}
\hline Variable & Df & $\sum$ of Sqrs & Mean Sqrs & F Model & $\mathrm{R}^{2}$ & $P(>\mathrm{F})$ \\
\hline Station & 3 & 0.634 & 0.21135 & 1.2336 & 0.15088 & 0.2112 \\
Date & 3 & 2.0264 & 0.67546 & 3.9426 & 0.4822 & 0.00001 \\
Residuals & 9 & 1.5419 & 0.17132 & 0.36692 & & \\
Total & 15 & 4.2023 & 1 & & & \\
\hline
\end{tabular}


NMDS Grouping by date

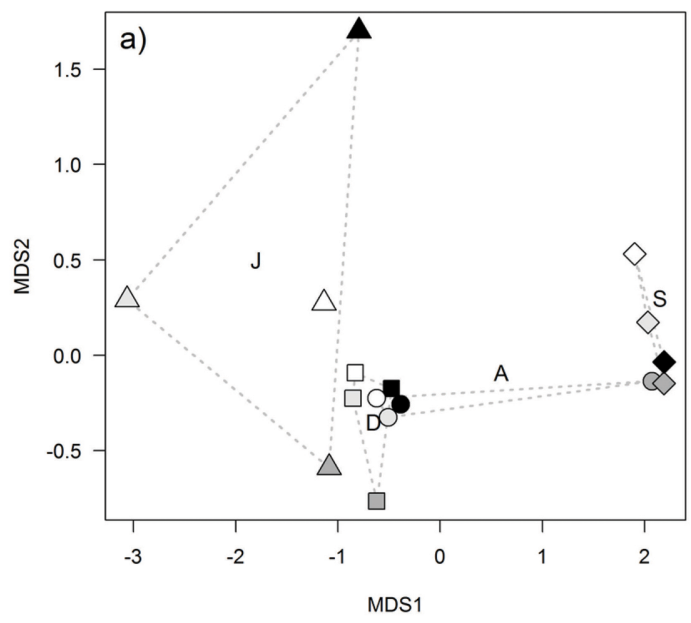

NMDS Grouping by station

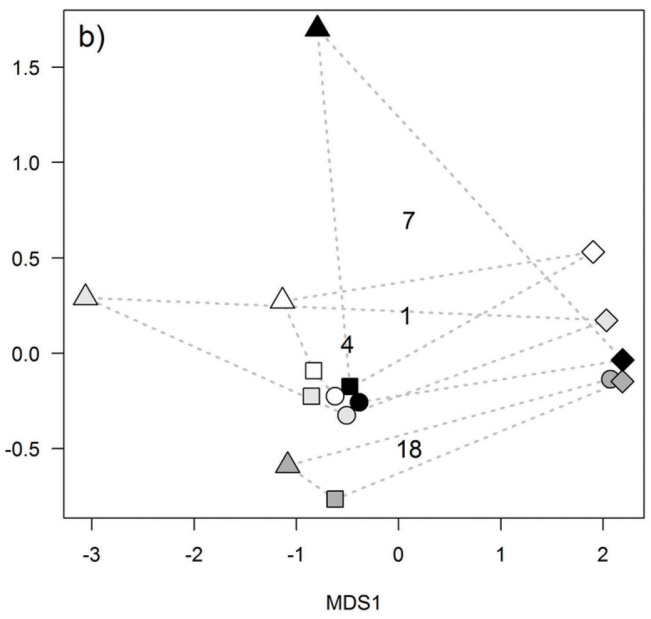

Figure 5. NM DS ordination based on relative abundance Bray-Curtis matrices of Actinobacteria OTUs. Samples were grouped by: (a) date of sampling,

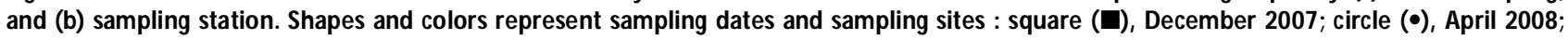
diamonds ( $\bullet$ ), September 2008; triangle ( $\triangle$ ), January 2009; white, station 1; light grey, station 4; dark grey, station 18; black, station 7. Dashed gray lines join samples collected in the same month or site / Ordenamiento NMDS basado en la abundancia relativa de OTUs de Actinobacteria y matrices de distancia de Bray-Curtis. Las muestras se agruparon por fecha de muestreo (a) o estación de muestreo (b). Las formas y colores de los

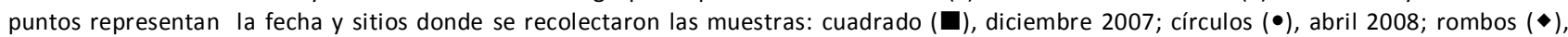
septiembre 2008; triángulos ( $\mathbf{\Delta}$ ), enero 2009; blanco, estación 1; gris claro, estación 4; gris oscuro, estación 18; negro, estación 7. Líneas punteadas grises unen las muestras recolectadas en el mismo mes o sitio

\section{Discussion}

In this study, we used amplicon sequencing of the hypervariable V6 region of the 16S rRNA to assess taxonomic diversity among Actinobacteria and elucidate temporal and spatial patterns in community structure. Actinobacteria is considered one of the 4 most abundant phyla in marine sediments (Zinger et al. 2011). In the studied sulfuretum Actinobacteria had a low $\left(7^{\text {th }}\right)$ ranking with only $2.9 \%$ of all pyrotags (data not shown). This overall low abundance differs from estimates by Duncan et al. (2014) for Actinobacteria isolated from various marine sediments, a feature that can be explained by the normal temporal interplay of oxygen-rich and oxygen-poor benthic conditions prevailing in the HS. Below, molecular taxonomy and community structure related findings of this abundant taxon are separately discussed.

\section{MOLECUlaR TAXONOMY AND BIOTECHNOLOGICAL POTENTIAL OF THE ACtinObaCteria FROM THE HS}

Culture-independent methods such as amplicon sequencing of DNA isolates have improved the understanding of ecological and diversity patterns in bacterial communities by using phylogenetic-based approaches (Hugenholtz et al. 1998). Because culture methods recover only between 1 and $10 \%$ of the total diversity recovered using DNA culture-independent methods (Bérdy 2005, Vartoukian et al. 2010), the latter present clear advantages to characterize unexplored environments (Das et al. 2006, Sogin et al. 2006). Vaz-Moreira et al. (2011) showed that culture-independent methods were more cost-effective than traditional culture methods. Furthermore, Duncan et al. (2014) suggest that cultureindependent methods are the most efficient in recovering the taxonomic diversity of microbial groups. Yet, describing new bacterial species and their phenotype will often require culturing them. New techniques were developed for culturing the 'as yet uncultivated' bacteria during the last decade (Vartoukian et al. 2010). These include: (i) use of simulated environments, (ii) co-culturing using 'helper strains', and (iii) single-cell isolation techniques that might help grow environmental bacteria never cultured before (Ishii et al. 2010, Vartoukian et al. 2010, Stewart 2012). In general, all these approaches promise to close the gap between culturable and unculturable bacteria (Aoi et al. 2009, Liu et al. 2009, Ishii et al. 2010, Nichols et al. 2010, Park et al. 2011).

In this study Actinomycetales was the dominant order. Over 10,000 bioactive compounds have been isolated from species of this order (Bérdy 2005). In this study 122 different genera were found, including Streptomyces, a genus known by its unmatched potential to produce secondary metabolites with 
anticarcinogenic, antitumor, antiviral, and antibiotic properties (Bérdy 2005, Dharmaraj 2010, Manivasagan et al. 2013). Genomic information from Salinispora tropica (Actinomycetes) revealed that $10 \%$ of its genome functions are related to the production of secondary metabolites (Udwary et al. 2007). Between 1997 and 2008, 660 new bacterial compounds were described that originated mainly from Actinobacteria (Williams 2009). Improvements on culturing the 'as yet unculturable' bacteria have been made in the last few years (Liu et al. 2009, Ishii et al. 2010, Nichols et al. 2010, Vartoukian et al. 2010). Even if it is not possible to culture a wild bacterial strain it is likely possible to synthetize its functions from genomic library information and insert it into a culturable bacteria (Iqbal et al. 2012, Church et al. 2014, Wright 2014).

\section{Community Structure of THE HS Actinobacteria}

Among the most striking ecological results of this study were the temporal changes in relative abundance and richness of Actinobacteria OTUs, which are linked to seasonal changes of upwelling conditions in the sea off central Chile. It was early found, (Ahumada \& Chuecas 1979), and later confirmed, that normally ('no El Niño regime') in the study area there is an alternation between two different regimes that affect the benthos: low-oxygen in spring-summer and high oxygen in autumn-winter (Gallardo et al. 1995, Paulmier et al. 2006, Sobarzo et al. 2007, Fuenzalida et al. 2009). Given that Actinobacteria are either aerobic or facultative anaerobes (Hogg 2005), the relative abundance and OTUs's richness should increase during the austral autumn-winter seasons, and decrease, during the austral spring-summer seasons, as it was found in this study. In freshwater, dissolved oxygen is also strongly correlated with seasonal changes and vertical stratification of bacterial communities (Martínez-Alonsoet al. 2008, Rotaru et al. 2012, Garcia et al. 2013). Pelagic marine and fresh-water Actinomycetales communities showed seasonal differences with depth and seasons presumably associated with changes in nutrient availability (Yoshida et al. 2008). Gallardo et al. (1995) surveyed the HS macrobenthic biota, including the megabacteria Candidatus Marithioploca spp. (ex-Thioploca, see Teske \& Salman 2014). This study found that the former's response to the seasonal and depth variations in dissolved oxygen are in tune with those shown in this study by Actinobacteria but not with respect to the behavior of the megabacteria Candidatus Marithioploca spp. which require the spring-summer reduced oxygen bottom conditions (Gallardo et al. 2013a).

Although evidence for spatially heterogeneous Actinobacteria OTUs was not supported by PERMANOVA analyses, 2 clusters were recognized: one represented by shallower ' $\mathrm{BoC}$
Stations' 1, 4, and 7, and another by the deeper open ocean 'off BoC Station' 18. It is hypothesized that this is an emerging bathymetric pattern that deserves further attention.

Both temporal and spatial patterns can be related to the movements, presence, and changes of water masses (Agogué et al. 2011, Salazar et al. 2015). Alves et al. (2015) found that parameters such as temperature, dissolved organic carbon, and depth appear to strongly influence the abundance and diversity of marine bacterial communities, and that the community structure might be related to features of the water masses present. They further suggest that the microbial component can help characterize each water mass. Brown et al. (2014) showed that bacterial communities in marine environments are highly structured and that biogeographic patterns reflect affinities for different water masses among bacteria. Water masses carrying different concentrations of oxygen, thus allowing for either organic-poor or organic-rich (reduced) benthic environments could structure benthic bacteria assemblages, and thus explain their eventual spatial and temporal variability as it has been confirmed by the present study.

\section{Conclusions}

As suggested by the important percentage of un-annotated tags, the lack of database information on uncultured bacteria needs to be addressed in order to provide more comprehensive assessments of bacterial diversity and ecology. Growth of genetic and taxonomic databases should enable more informed conclusions based on molecular, culture-independent data. In this study, using culture-independent methods the diversity and dynamics of the Actinobacteria community collected from marine sediments in the HS were characterized. Results indicated that the highly dynamic seasonal environment of the Humboldt Current system can explain temporal and spatial patterns in the Actinobacteria community structure. Molecular taxonomy based on V6 pyrotags promises to illuminate community diversity among other bacterial phyla found in sediments at the BoC and adjacent continental shelf. A large proportion of the OTUs had no matches in any database and remained anonymous. Yet, we found 5 genera that have been widely recognized for their biotechnological applications. Therefore, the HS appears as an untapped source of secondary metabolites.

\section{ACKNOWLEDGMENTS}

We thank the global program Census of Marine Life (CoML) through its founder and coordinator, Prof. Dr. Jesse Ausubel, University of Rockefeller, New York, U.S.A. We also thank to Dr. Mitchel Sogin and his team at the Marine Biology Laboratory, Woods Hole, Massachusetts, U.S.A. leader of the 
International Census of Marine Microbes. This work was possible thanks to FONDECYT grants 1070552 and 1110786 , and of an Enlace grant from the University of Concepción to VAG and CEF. We also thank the crew of R/V KAY-KAY II from Universidad de Concepción, Chile.

\section{LITERATURE CITED}

Adegboye MF \& OO Babalola. 2012. Taxonomy and ecology of antibiotic producing actinomycetes. African Journal of Agricultural Research 7: 15.

Agogué H, D Lamy, PR Neal, ML Sogin \& GJ Herndl. 2011. Water mass-specificity of bacterial communities in the North Atlantic revealed by massively parallel sequencing. Molecular Ecology 20(2): 258-274.

Ahumada R \& L Chuecas. 1979. Algunas características

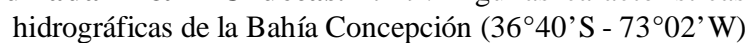
y áreas adyacentes, Chile. Gayana, Miscelánea 8: 1-56.

Alves N Jr, P Milet-Meirelles, E de Oliveira Santos, B Dutilh, GZ Silva, R Paranhos, AS Cabral, C Rezende, T lida, RL de Moura, R Henrique Kruger, RC Pereira, $R$ Valle, T Sawabe, C Thompson \& F Thompson. 2015. Microbial community diversity and physical-chemical features of the Southwestern Atlantic Ocean. Archives of Microbiology 197(2): 165-179.

Amaral-Zettler L, LF Artigas, J Baross, PA Bharathi-Loka, A Boetius, D Chandramohan, G Herndl, K Kogure, P Neal, C Pedrós-Alió, A Ramette, S Schouten, L Stal, A Thessen, J de Leeuw \& M Sogin. 2010. A global census of marine microbes. In: McIntyre A (ed). Life in the World's Oceans, pp. 221-245, Wiley-Blackwell, Chichester.

Anderson MJ. 2001. A new method for non-parametric multivariate analysis of variance. Austral Ecology 26(1):32-46.

Aoi Y, T Kinoshita, T Hata, H Ohta, H Obokata \& S Tsuneda. 2009. Hollow-fiber membrane chamber as a device for in situ environmental cultivation. Applied and Environmental Microbiology 75(11):3826-3833.

Bérdy J. 2005. Bioactive microbial metabolites. Journal of Antibiotics 58(1): 1-26.

Bik HM, DL Porazinska, S Creer, JG Caporaso, R Knight \& WK Thomas. 2012. Sequencing our way towards understanding global eukaryotic biodiversity. Trends in Ecology \& Evolution 27(4): 233-243.

Brown MV, M Ostrowski, JJ Grzymski \& FM Lauro. 2014. A trait based perspective on the biogeography of common and abundant marine bacterioplankton clades. Marine Genomics 15: 17-28.

Bunge J. 2011. Estimating the number of species with CatchAll. Pacific Symposium on Biocomputing 16: 121-130.

Caporaso JG, CL Lauber, WA Walters, D Berg-Lyons, CA Lozupone, PJ Turnbaugh, N Fierer \& R Knight. 2011. Global patterns of $16 \mathrm{~S}$ rRNA diversity at a depth of millions of sequences per sample. Proceedings of the National Academy of Sciences 108(Suppl. 1): 4516-4522.
Cho JY, HC Kwon, PG Williams, CA Kauffman, PR Jensen \& W Fenical. 2006. Actinofuranones A and B, polyketides from a marine-derived bacterium related to the genus Streptomyces (Actinomycetales). Journal of Natural Products 69(3): 425-428.

Church GM, MB Elowitz, CD Smolke, CA Voigt \& R Weiss. 2014. Realizing the potential of synthetic biology. Nature Reviews Molecular Cell Biology 15(4): 289-294.

Das S, P Lyla \& SA Khan. 2006. Marine microbial diversity and ecology: importance and future perspectives. Current Science 90(10): 1325-1335.

Deutschbauer AM, D Chivian \& AP Arkin. 2006. Genomics for environmental microbiology. Current Opinion in Biotechnology 17(3): 229-235.

Dharmaraj S. 2010. Marine Streptomyces as a novel source of bioactive substances. World Journal of Microbiology and Biotechnology 26(12): 2123-2139.

Duncan K, B Haltli, K Gill \& R Kerr. 2014. Bioprospecting from marine sediments of New Brunswick, Canada: Exploring the relationship between total bacterial diversity and Actinobacteria diversity. Marine Drugs 12(2): 899-925.

Fakruddin M \& A Chowdhury. 2012. Pyrosequencing-an alternative to traditional Sanger sequencing. American Journal of Biochemistry and Biotechnology 8(1): 14-20.

Fandino LB, L Riemann, GF Steward, RA Long \& F Azam. 2001. Variations in bacterial community structure during a dinoflagellate bloom analyzed by DGGE and 16S rDNA sequencing. Aquatic Microbial Ecology 23(2): 119-130.

Fiedler HP, C Bruntner, AT Bull, A Ward, M Goodfellow, O Potterat, C Puder \& G Mihm. 2005. Marine actinomycetes as a source of novel secondary metabolites. Antonie Van Leeuwenhoek 87(1): 37-42.

Fossing H, VA Gallardo, S Pantoja, J Harder, M Hüttel, LP Nielsen, H Schulz, DE Canfield, S Forster, RN Glud, JK Gundersen, J Küver, NB Ramsing, A Teske, B Thamdrup \& O Ulloa. 1995. Concentration and transport of nitrate by the mat-forming sulphur bacterium Thioploca. Nature 374(6524): 713-715.

Fuenzalida R, W Schneider, J Garcés-Vargas, L Bravo \& C Lange. 2009. Vertical and horizontal extension of the oxygen minimum zone in the eastern South Pacific Ocean. Deep-Sea Research II, 56: 992-1003.

Galand PE, EO Casamayor, DL Kirchman \& C Lovejoy. 2009. Ecology of the rare microbial biosphere of the Arctic Ocean. Proceedings of the National Academy of Sciences 106(52): 22427-22432.

Gallardo A. 1963. Notas sobre la densidad de la fauna bentónica en el sublitoral del norte de Chile. Gayana, Zoología 10: 3-15.

Gallardo VA. 1975. On the benthic sulphide system on the continental shelf of north and central Chile. Proceedings Seminario Internacional de Surgencias, Universidad del Norte, Sede Coquimbo, pp. 113-118.

Gallardo VA. 1977a. Large benthic microbial communities in sulphide biota under Peru-Chile Subsurface Countercurrent. Nature 268(5618): 331-332. 
Gallardo VA. 1977b. On the discovery of a large microbial community living in the bottoms of the continental shelf off Chile and Peru. In: Anales del Instituto de Investigaciones Marinas de Punta Bentín (eds). Memorias del Seminario Internacional sobre Problemas de la Ecología Marina Actual y el Futuro del Hombre, pp. 23-30. Anales del Instituto de Investigaciones Marinas de Punta Bentín, Medellín.

Gallardo VA \& C Espinoza. 2007a. New communities of large filamentous sulfur bacteria in the eastern South Pacific. International Microbiology 10(2): 97-102.

Gallardo VA \& C Espinoza. 2007b. Large multicellular filamentous bacteria under the oxygen minimum zone of the eastern South Pacific: a forgotten biosphere. Proc. SPIE 6694, Instruments, Methods, and Missions for Astrobiology X: Proceedings of SPIE 66941H <doi:10.1117/12.782209>

Gallardo VA, FD Carrasco, R Roa \& JI Cañete. 1995. Ecological patterns in the benthic macrobiota across the continental shelf off central Chile. Ophelia 40(3): 167-188.

Gallardo VA, C Espinoza, A Fonseca \& SS Musleh. 2013a. Las grandes bacterias del Sulfureto de Humboldt. Gayana 77(2): 136-170.

Gallardo VA, A Fonseca, SS Musleh \& C Espinoza. 2013b. Extrapolations of standing-stocks of big bacteria in Humboldt eastern boundary current ecosystem (HEBCE). Oceanography 1: 110 <doi: 10.4172/2332-2632.1000110>

Gallardo VA, A Fonseca, C Espinoza, N Ruiz-Tagle \& S Musleh. 2015. Bacteria of the Humboldt sulfuretum comply with unifying macroecological principles. Marine Biodiversity <doi:10.101007/s12526-015-0377-x>

Garcia SL, I Salka, H-P Grossart \& F Warnecke. 2013. Depth-discrete profiles of bacterial communities reveal pronounced spatio-temporal dynamics related to lake stratification. Environmental Microbiology Reports 5(4): 549555.

Goodfellow M \& HP Fiedler. 2010. A guide to successful bioprospecting: informed by actinobacterial systematics. Antonie Van Leeuwenhoek 98(2): 119-142.

Hansel CM, S Fendorf, PM Jardine \& CA Francis. 2008. Changes in bacterial and archaeal community structure and functional diversity along a geochemically variable soil profile. Applied and Environmental Microbiology 74(5): 1620-1633.

Hogg S. 2005. Essential microbiology, 480 pp. Wiley, Chichester.

Høgslund S, NP Revsbech, T Cedhagen, LP Nielsen \& VA Gallardo. 2008. Denitrification, nitrate turnover, and aerobic respiration by benthic foraminiferan's in the oxygen minimum zone off Chile. Journal of Experimental Marine Biology and Ecology 359: 85-91.

Huber JA, DB Mark Welch, HG Morrison, SM Huse, PR Neal, DA Butterfield \& ML Sogin. 2007. Microbial population structures in the deep marine biosphere. Science 318(5847): 97-100.

Hugenholtz P, BM Goebel \& NR Pace. 1998. Impact of culture-independent studies on the emerging phylogenetic view of bacterial diversity. Journal of Bacteriology 180(18): 4765-4774.
Huse SM, DM Welch, HG Morrison \& ML Sogin. 2010. Ironing out the wrinkles in the rare biosphere through improved OTUs clustering. Environmental Microbiology 12(7): $1889-1898$.

Huse SM, J Huber, H Morrison, ML Sogin \& D Welch. 2007. Accuracy and quality of massively parallel DNA pyrosequencing. Genome Biology 8(7): R143.

Huse SM, L Dethlefsen, JA Huber, DM Welch, DA Relman \& ML Sogin. 2008. Exploring microbial diversity and taxonomy using SSU rRNA hypervariable tag sequencing. PLOS Genetics 4(11): e1000255.

Iqbal HA, Z Feng \& SF Brady. 2012. Biocatalysts and small molecule products from metagenomic studies. Current Opinion in Chemical Biology 16(1-2): 109-116.

Ishii S, K Tago \& K Senoo. 2010. Single-cell analysis and isolation for microbiology and biotechnology: methods and applications. Applied Microbiology and Biotechnology 86(5): 1281-1292.

Jensen PR, TJ Mincer, PG Williams \& W Fenical. 2005. Marine actinomycete diversity and natural product discovery. Antonie Van Leeuwenhoek 87(1): 43-48.

Kruskal JB. 1964. Nonmetric multidimensional scaling: A numerical method. Psychometrika 29(2): 115-129.

Lam KS. 2006. Discovery of novel metabolites from marine actinomycetes. Current Opinion in Microbiology 9(3): 245251.

Li X, S Vanner, W Wang, Y Li, VA Gallardo \& N Magarvey. 2013. Macplocimine A, a new 18-membered macrolide isolated from the filamentous sulfur bacteria Thioploca $\mathrm{sp}$. The Journal of Antibiotics 66: 443-446.

Liu W, HJ Kim, EM Lucchetta, W Du \& RF Ismagilov. 2009. Isolation, incubation, and parallel functional testing and identification by FISH of rare microbial single-copy cells from multi-species mixtures using the combination of chemistrode and stochastic confinement. Lab on a Chip 9(15):2153-2162.

Manivasagan P, J Venkatesan, K Sivakumar \& SK Kim. 2013. Marine actinobacterial metabolites: Current status and future perspectives. Microbiological Research 168(6): 311-332.

Mantel N \& RS Valand. 1970. A technique of nonparametric multivariate analysis. Biometrics 26(3): 547-558.

Martínez-Alonso M, S Méndez-Álvarez, S Ramírez-Moreno, E González-Toril, R Amils \& N Gaju. 2008. Spatial heterogeneity of bacterial populations in monomictic lake Estanya (Huesca, Spain). Microbial Ecology 55(4): 737-750.

McArdle BH \& MJ Anderson. 2001. Fitting multivariate models to community data: A comment on distance-based redundancy analysis. Ecology 82(1): 290-297.

Nichols D, N Cahoon, EM Trakhtenberg, L Pham, A Mehta, A Belanger, T Kanigan, K Lewis \& SS Epstein. 2010. Use of Ichip for high-throughput in situ cultivation of 'uncultivable' microbial species. Applied and Environmental Microbiology 76(8): 2445-2450. 
Oksanen J, G Blanchet, R Kindt, P Legendre, P Minchin, RB O'Hara, G Simpson, P Solymos, H Stevens \& H Wagner. 2015. vegan: Community ecology package, Version 2.3. <https://cran.r-project.org/web/packages/vegan/ index.html >

Park J, A Kerner, MA Burns \& XN Lin. 2011. MicrodropletEnabled highly parallel co-cultivation of microbial communities. PLoS ONE 6(2): e17019.

Pedrós-Alió C. 2012. The rare bacterial biosphere. Annual Review of Marine Science 4: 449-466.

Paulmier A, D Ruiz-Pino, V Garçon \& L Farías. 2006. Maintaining of the Eastern South Pacific Oxygen Minimum Zone (OMZ) off Chile. Geophysical Research Letters 33(20): L20601 <doi:10.1029/2006GL026801〉

Quince C, A Lanzen, R Davenport \& P Turnbaugh. 2011. Removing noise from pyrosequenced amplicons. BMC Bioinformatics 12(1): 38 .

R Core Team. 2015. R: A language and environment for statistical computing. R Foundation for Statistical Computing, Version 3.2.2. <https://cran.r-project.org>

Rappé MS \& SJ Giovannoni. 2003. The uncultured microbial majority. Annual Review of Microbiology 57(1): 369-394.

Rosselló-Mora R \& R Amann. 2001. The species concept for prokaryotes. FEMS Microbiology Reviews 25(1): 39-67.

Rotaru C, T Woodard, S Choi \& K Nevin. 2012. Spatial heterogeneity of bacterial communities in sediments from an infiltration basin receiving highway runoff. Microbial Ecology 64(2): 461-473.

Salazar G, FM Cornejo-Castillo, V Benitez-Barrios, E Fraile-Nuez, XA Alvarez-Salgado, CM Duarte, JM Gasol \& SG Acinas. 2015. Global diversity and biogeography of deep-sea pelagic prokaryotes. The ISME Journal <doi:10.1038/ismej.2015.137>

Sobarzo M, L Bravo, D Donoso, J Garcés-Vargas \& W Schneider. 2007. Coastal upwelling and seasonal cycles that influence the water column over the continental shelf off central Chile. Progress in Oceanography 75(3): 363-382.

Sogin ML, HG Morrison, JA Huber, DM Welch, SM Huse, PR Neal, JM Arrieta \& GJ Herndl. 2006. Microbial diversity in the deep sea and the underexplored «rare biosphere». Proceedings of the National Academy of Sciences 103(32): 12115-12120.

Stewart EJ. 2012. Growing unculturable bacteria. Journal of Bacteriology 194(16): 4151-4160.

Sul WJ, TA Oliver, HW Ducklow, LA Amaral-Zettler \& ML Sogin. 2013. Marine bacteria exhibit a bipolar distribution. Proceedings of the National Academy of Sciences 110(6): 2342-2347.
Teske A \& V Salman. 2014. The Family Beggiatoaceae. In: Rosenberg E, EF DeLong, S Lory, E Stackenbrandt \& F Thompson (eds). The Prokaryotes, Gammaproteobacteria, pp. 94-134. Springer, New Delhi.

Tremberger G, VA Gallardo, C Espinoza, T Holden, N Gadura, E Cheung, P Schneider, D Lieberman \& T Cheung. 2010. Archaeon and archaeal virus diversity classification via sequence entropy and fractal dimension. In: Hoover RB, GV Levin, A Yu, P Rosanov \& CW Davies (eds). Instruments, methods, and missions for Astrobiology XIII, Proceedings of SPIE. Vol. 7819, 78190T.2010 SPIE <doi: 101117/12.860097>

Udwary DW, L Zeigler, RN Asolkar, V Singan, A Lapidus, W Fenical, PR Jensen \& BS Moore. 2007. Genome sequencing reveals complex secondary metabolome in the marine actinomycete Salinispora tropica. Proceedings of the National Academy of Sciences 104(25): 10376-10381.

Ulloa O, DE Canfield, EF DeLong, RM Letelier \& FJ Stewart. 2012. Microbial oceanography of anoxic oxygen minimum zones. Proceedings of the National Academy of Sciences 109(40): 15996-16003.

Vartoukian SR, RM Palmer \& WG Wade. 2010. Strategies for culture of 'unculturable' bacteria. FEMS Microbiology Letters 309(1): 1-7.

Vaz-Moreira I, C Egas, O Nunes \& C Manaia. 2011. Culture-dependent and culture-independent diversity surveys target different bacteria: a case study in a freshwater sample. Antonie Van Leeuwenhoek 100(2): 245-257.

Ward AC \& N Bora. 2006. Diversity and biogeography of marine Actinobacteria. Current Opinion in Microbiology 9(3): 279-286.

Williams PG. 2009. Panning for chemical gold: marine bacteria as a source of new therapeutics. Trends in Biotechnology 27(1):45-52.

Wright G. 2014. Perspective: Synthetic biology revives antibiotics. Nature 509(7498): S13-S13.

Yoshida A, Y Seo, S Suzuki, T Nishino, T Kobayashi, N Hamada-Sato, K Kogure \& C Imada. 2008. Actinomycetal community structures in seawater and freshwater examined by DGGE analysis of 16S rRNA gene fragments. Marine Biotechnology 10(5): 554-563.

Zhou J, B Xia, DS Treves, L-Y Wu, TL Marsh, RV O'Neill, AV Palumbo \& JM Tiedje. 2002. Spatial and resource factors influencing high microbial diversity in soil. Applied and Environmental Microbiology 68(1): 326-334.

Zinger L, LA Amaral-Zettler, JA Fuhrman, MC HornerDevine, SM Huse, DBM Welch, JBH Martiny, M Sogin, A Boetius \& A Ramette. 2011. Global patterns of bacterial beta-diversity in seafloor and seawater ecosystems. PLoS ONE 6(9): e24570. 
Table S1. Genera with useful secondary metabolites accordingto Adegboye \& Bablola (2012), Cho et al. (2006), Fiedler et al. (2005), Goodfellow \& Fiedler (2010), Jensen et al. (2005), Lam (2006), Mincer et al. (2005) / Géneros con metabolitos secundarios útiles según: Adegboye \& Babalola (2012), Cho et al. (2006), Fiedler et al. (2005), Goodfellow \& Fiedler (2010), Jensen et al. (2005), Lam (2006), Mincer et al. (2005)

\begin{tabular}{|c|c|c|c|c|}
\hline Genus & $\begin{array}{l}\mathrm{N} \text { of } \mathrm{V} 6 \\
\text { pyrotag }\end{array}$ & $\begin{array}{l}\mathrm{N} \text { of } \\
\text { OTUs }\end{array}$ & Metabolites & Uses \\
\hline Streptomyces & 205 & 34 & $\begin{array}{c}\text { Aureoverticillactam } \\
\text { Frigocyclinone } \\
\text { Lajollamycin } \\
\text { Bonactin } \\
\text { Caprolactones } \\
\text { Chinikomycins } \\
\text { 3,6-disubstituted indoles } \\
\text { Glaciapyrroles } \\
\text { Gutingimycin } \\
\text { Himalomycins } \\
\text { Komodoquinone A } \\
\text { Trioxacarcins } \\
\text { Albidopyrone } \\
\text { Abyssomicins B, C, atrop-C, D, G and H } \\
\text { Benzoxazine NTK } 935 \\
\text { Caboxamycin }\end{array}$ & $\begin{array}{c}\text { Anticancer } \\
\text { Antibacterial } \\
\text { Antibacterial } \\
\text { Antibacterial; antifungal } \\
\text { Anticancer } \\
\text { Anticancer } \\
\text { Anticancer } \\
\text { Antibacterial } \\
\text { Antibacterial } \\
\text { Antibacterial } \\
\text { Neuritogenic activity } \\
\text { Antibacterial; anticancer; antimalarial } \\
\text { Antibiotics } \\
\text { Inhibitory activity against protein-tyrosine phosphatase B } \\
\text { Antibiotic }\end{array}$ \\
\hline Micromonospora & 20 & 10 & Diazepinomicin (ECO-4601) & Antibacterial; anticancer; anti-inflammatory \\
\hline Actinomadura & 3 & 2 & Chandrananimycins IB-00208 & Antialagl; antibacterial; anticancer; antifungal; Anticancer \\
\hline Dermacoccus & 2 & 1 & Dermacozines & Antitumour; antiprotozoal and free radical scavenging activities \\
\hline Tsukamurella & 1 & 1 & Lipocarbazoles A1-A4 & Strong free radical scavenging activity \\
\hline
\end{tabular}

